\title{
ANALISIS KREATIVITAS SISWA KELAS III SD SWASTA YAYASAN WANITA KERETA API "YWKA" MEDAN DALAM PEMBELAJARAN MENGGAMBAR BINATANG
}

\author{
Teguh Iman Perdana Surbakti ${ }^{1 *}$, Zulkifli $^{2 *}$, Wahyu Tri Atmojo ${ }^{3^{*}}$, Mesra $^{4^{*}}$ \\ Program Studi Pendidikan Seni Rupa Jurusan Seni Rupa Fakultas Bahasa dan Seni \\ Universitas Negeri Medan \\ Jl. Willem Iskandar Pasar V Medan Estate, Kec, Percut Sei Tuan, Kab. Deli Serdang, Kode Pos 20371 \\ Sumatera Utara. Indonesia \\ Email: teguhimamperdas@gmail.com
}

\begin{abstract}
Abstrak
Penelitian ini dilakukan di SD Swasta Yayasan Wanita Kereta Api "YWKA" Medan yang bertujuan untuk menganalisis kreatifitas dan potensi siswa dalam pembelajaran menggambar binatang bertema burung. Metode pengumpulan data penelitian ini adalah observasi, wawancara dan dokumentasi. Populasi dalam penelitian ini adalah seluruh siswa kelas III SD Swasta Yayasan Wanita Kereta Api "YWKA" Medan. Pengambilan sampel menggunakan teknik sampel jenuh (semua anggota populasi dijadikan sampel) diperoleh sampel penelitianya itu sebanyak 25 orang dari kls III. Hasil penelitian ini menunjukkan bahwa aspek yang dikembangkan dalam teori Utami Munandar 4P dalam pengembangan kreativitas yaitu pribadi kreatif, pendorong (press), proses kreatif, dan produk berdasarkan hasil nilai rata-rata yang telah dinilai oleh 3 tim penilai secara keseluruhan pada karya menggambar binatang bertema burung siswa kelas III SD Swasta Yayasan Wanita Kereta Api "YWKA" Medan. Hasil penelitian menjelaskan bahwa aspek pribadi secara keseluran baik karena dari hasil karya siswa sudah memenuhi ketiga deskriptor dari empat deskriptor yang sudah ditentukan. Pendorong secara keseluruhan cukup baik karena karya siswa hanya memenuhi dua deskriptor dari empat deskriptor yang ditentukan. Aspek proses secara keseluruhan cukup baik karena karya siswa hanya memenuhi dua deskriptor dari empat deskriptor yang ditentukan. Aspek produk secara keseluruhan cukup baik karena karena karya siswa hanya memenuhi dua deskriptor dari empat deskriptor yang ditentukan.
\end{abstract}

Kata Kunci: analisis, kreativitas, menggambar binatang.

\begin{abstract}
This research was conducted by the SD Swasta Yayasan Wanita Kereta Api "YWKA" Medan which aims to analyze the potential of students in bird-themed animal learning. Data collection methods in this study are observation, interviews and documentation. This population study is all third grade students from the SD Swasta Yayasan Wanita Kereta Api "YWKA" Medan. Sampling using saturated sample techniques (all members of the population used as samples) obtained a study sample of 25 people from third grade. The theory of creativity and motivation is based on the results of a study in Utami in the third grade of 4P Munandar SD Swasta Yayasan Wanita Kereta Api "YWKA" Medan. The results of this study are the three descriptors of four predefined descriptors. The overall driver is quite good because only descriptors from four descriptors are specified. The whole process is quite good because it only fulfills two explanations of the four specified explanations. The whole product is quite good because it only satisfies two descriptors from the four specified descriptors.
\end{abstract}

Keywords: analysis, creativity, drawing's animals.

\section{PENDAHULUAN}

Pendidikan merupakan kebutuhan mendasar yang harus dijalani setiap manusia, karena pendidikan mampu menghasilkan pribadi yang berkualitas. Diera globalisasi saat ini, perlu generasi muda yang kereatif dan inovatif karna di era sekarang tidak hanya mengandalkan kecerdasan akademik saja. Sehingga anak perlu dibina dan dilatih sejak dini untuk mengembangkan potensi dan kreativitasnya.

Salah satu upaya yang dapat dilakukan untuk megembangkan kreativitas anak adalah dengan meggambar, melipat, meronce, dan mewarnai. Marwah Nazhifah Sitorus (2017) dalam penelitiannya "Pengaruh Kegiatan Menggambar Terhadap 


\author{
Gorga Jurnal Seni Rupa \\ Volume 08 Nomor 01 Januari-Juni 2019 \\ p-ISSN: 2301-5942 | e-ISSN: 2580-2380
}

Pengembangan Kreativitas Anak 4-5 Tahun di TK ABA 05 Medan Tahun 2016/2017’. Menyimpulkan bahwa kegiatan menggambar sangat berpengaruh terhadap pengembangan kreativitas.

Sejalan dengan itu pembelajaran menggambar adalah salah satu mata pelajaran yang berperan strategis dalam pengembangan kreativitas anak. Pembelajaran keterampilan dan kesenian sama halnya melatih pola pikiran anak agar kreatif, inovatif dan responsive dalam memecahkan masalah yang dihadapi. Pelajaran menggambar juga tidak hanya berperan dalam mengolah kesiapan dan kemampuan dasar anak dalam belajar, meningkatkan kecerdasan emosi anak, tetapi juga penting untuk melatih anak mengembangkan potensi dan kreativitasnya.

Pembelajaran menggambar dalam sistem pelaksanaannya di SD Yayasan Wanita Kereta Api "YWKA" Medan kelas III yang peneliti pilih sebagai tempat dilakukannya penelitian masih dalam kurikulum mata pelajaran Seni Budaya dan Keterampilan (SBK). Pembelajaran dalam Rencana Pelaksanaan Pembelajaran (RPP) semester II dibagi menjadi 4 materi pembelajaran yaitu; menggambar , musik , tari dan keterampilan dengan alokasi waktu masing-masing 2 x 45 menit dalam 3 kali petemuan. Keterbatas waktu pembelajaran menggambar di sekolah menyebabkan anak tidak memiliki waktu yang cukup untuk latihan menggambar. Kurangnya latihan anak dalam menggambar membuat anak tidak terbiasa dalam peroses menggambar yang menyebabkan tidak terlihatnya perkembangan potensi anak dalam menggambar.

Sejalan dengan pendapat Wasliman dalam Ahmad (2013:13) bahwa sekolah merupkan salah satu faktor yang ikut menentukan hasil belajar siswa. Kurangnya waktu pembelajaran menggambar di sekolah menyebabkan kurangnya pengalaman anak dalam pembelajaran menggambar sehinnga dapat dilihat dari daftar nilai siswa pada semester genap di SD Swasta Yayasan Wanita Kereta Api "YWKA" Medan dikelas III, menunjukkan dari seluruh siswa kelas III yang berjumlah 25 siswa, hanya 9 (36\%) siswa karya yang dinilai baik dan 16 (64\%) siswa karya yang dinilai kurang baik.

Nilai tersebut berasal dari hasil belajar siswa pada semester genap. Salah satu faktor yang peneliti lihat dari peroses pembelajaran saat melakukan studi pendahuluan metode yang di lakukan guru adalah guru hanya memberi contoh satu gambar yang harus diikuti oleh siswa, sehingga tidak terlihat kemampuan siswa dalam berkrativitas. Hal itu terjadi karena guru yang mengajarkan tentang menggambar bukanlah guru seni rupa melainkan guru matimatika. Winna dalam Ahmad (2013:13) menjelaskan bahwa guru adalah komponen yang sangat menentukan dalam implementasi suatu strategi pembelajaran.

Guru dituntut untuk dapat mengembangkan keterampilan dalam membuat media dalam pelaksanaan pembelajaran. Untuk itu guru harus memiliki pengetahuan dan pemahaman tentang media pembelajaran. Peran orangtua juga sangat berpengaruh dalam peroses perkembangan potensi dan kreativitas menggambar siswa. Berdasarkan hasil studi latar belakang yang dilakukan oleh peneliti dengan pembagian angket terhadap orang tua siswa kelas III SD Swasta Yayasan Wanita Kereta Api "YWKA" Medan dapat dilihat bahwa dari 25 angket yang di bagikan tehadap orang tua siswa hanya $3(12 \%)$ orang tua yang mendukung anaknya melakukan kegiatan yang berhubungan dengan menggambar dan 5 (20\%) orang tua siswa memilih kegiatan yang berhubungan dengan olahraga dan $17(68 \%)$ orang tua yang memilih kegiatan yang berhubungan dengan akademik seperti les berhitung dan bahasa.

Berdasarkan uraian di atas penulis mengambil sekolah SD Swasta Yayasan Wanita Kereta Api "YWKA" Medan sebagai lokasi penelitian dikarenakan masih adanya kekurangan dalam bidang studi Seni Budaya dan Keterampilan khususnya dalam mata pelajran menggambar, sebagai tema gambar dari penelitian tersebut adalah menggambar binatang bertema burung.

\section{KAJIAN TEORI}

\section{Kreativitas}

Kreativitas mengandung beberapa defenisi, Al-Khali (2005:17) menyatakan bahwa kreativitas anak-anak sebenarnya adalah sutau pemikiran yang memiliki hasil cipta, bukan rutinitas atau sekedar mengikuti mode. Utami (1992:47) bahwa kreativitas adalah kemampuan untuk membuat kombinasi baru, berdasarkan data, informai, atau unsur-unsur yang ada.

Pendapat lain dikemukakan oleh Mesra ( 2013 : 41 ) menuliskan :"Kreativitas (creativity) berasal darikata kreatif ( creative) yang berarti memiliki daya cipta. Dalam kehidupan sehari-hari kita sering mendengar orang mengatakan kreatif tehadap prilaku orang menciptakan sesuatu yang baru. Baru dalam arti lain dari pada yang belum pernah ada samasekali, terus menjadi sama ada, tetapi bisa saja menambah. Mengembangkan, mengkombinasikan, ataupun 


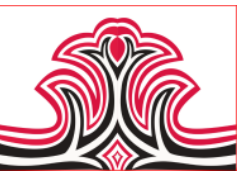

menguragi dari bentuk-bentuk yang sudah ada". Kreatif merupakan suatu sifat yang dimiliki oleh seseorang yang mempunyai kreativitas. Hal ini dikarenakan hanya orang kreatif yang mempunyai ide gagasan kreatif dan original. Orang akan menjadi kreatif apabila distimulasi sejak dini. Anak dikatakan kreatif apabila mampu menghasilkan produk secara kreatif serta tidak tergantung dengan orang lain yang berarti bahwa dalam memuaskan diri bukan karena tekanan dari luar.

Sugito dan Wahyu (2014:55) menjelaskan bahwa kreativitas merupakan kegiatan yang dilakukan orang setiap hari, hal itu dapat ditandai dengan adanya perkembangan, perubahan, dari waktu ke waktu dalam segala sendi kehidupan, namun demikian istilah kreativitas umumnya dianggap orang suatu aktivitas yang selalu benhubungan dengan bidang seni, meski anggapan itu dapat dibenarkan karena aktivitas bidang seni lekat dengan cipta kreasi, atau kreativitas selalu dihubungkan dengan suatu penemuan yang luar biasa.

Jhon (2007:342) berpendapat bahwa kreativitas adalah kemampuan untuk berfikir dalam cara-cara yang baru dan tidak bisa serta menghasilkan pemecahan masalah yang unik. Dari paparan tersebut dapat disimpulkan bahwa kreativitas adalah suatu kemampuan untuk menghasilkan gagasan baru, memecahkan masalah, dan ide serta mempunyai maksud dan tujuan yang ditentukan. Kreativitas dalam bidang seni diartikan sebagai berkarya yaitu suatu kemampuan untuk mewujudkan karya seni sebagai hasil kreativitasnya.

\section{Menggambar Binatang}

Menurut Veri (2004:6) gambar merupakan bahasa yang universal dan berkembang sebelum ditemukannya bahasa tulisan. Sembiring (2014:25) menjelaskan bahwa gambar dalam bahasa inggris disebut Drawing, adalah cabang seni rupa dua dimensional yang produk akhirnya berupa gambar. Unsur-unsur bentuknya didominasi titik, garis dan bidang-bidang yang umumnya tidak berwarna warni (biasanya hitam putih). Berdasarkan beberapa pendapat diatas maka dapat disimpulkan bahwa menggambar adalah suatu wujud hasil pemikiran manusia sebagai kegiatan yang berhubungan dangan imajinasi atau ingatan.

Menggambar juga merupakan proses atau cara pembuatan suatu kegiatan ekspresi kreatif yang populer dikalangan anak-anak. Pengalaman batin yang sederhana pada anak-anak merupakan kenangan indah dan hangat yang sewaktu- waktu bisa diungkapkan dengan bereksperasi dan juga merupakan pendorong
Gorga Jurnal Seni Rupa

Volume 08 Nomor 01 Januari-Juni 2019

p-ISSN: 2301-5942 | e-ISSN: 2580-2380

baginya. Sebagian besar kehidupan anak-anak dipenuhi dengan permainan.

Menurut pendapat Veri (2004:7) tentang menggambar adalah perpaduan keterampilan ( $s k i l l)$, kepekaan rasa (taste), kreativitas, ide, pengetahuan, dan wawasan. Menggambar juga merupakan kegiatan coret-mencoret yaitu perkembangan motorik anak dan anak sangat menyenangi kegiatan ini, sehingga dengan dorongan guru dan kesempatan yang diberikan kepada anak akan rmotivasinya membuat gambar. Sedangkan kegiatan menggambar merupakan salah satu cara manusia mengekspresikan pikiran-pikiran atau perasaan- perasaanya. Dengan kata lain gambar merupakan salah satu bentuk bahasa. Dari kutipankutipan diatas dapat disimpulkan menggambar adalah kegiatan membuat objek dengan bentuk dua dimensi dipermukaan bidang datar dengan menggunkan alat dan bahan gambar untuk memvisualisasikan objek dengan aspek bentuk, warna dan komposisi.

Sedangkan kata binatang dengan jenis burung disini merupakan sebagai salah satu objek dalam menggambar yaitu berupa mahluk hidup yang mampu bergerak dan mampu berinteraksi terhadap rangsangan, tetapi tidak berakal budi. Sehinggga dapat disimpulkan menggambar binatang adalah kegiatan membuat objek binatang dengan bentuk dua dimensi dipermukaan bidang datar denggan menggunakan alat dan bahan gambar untuk memvisualisasikan burung tersebut.

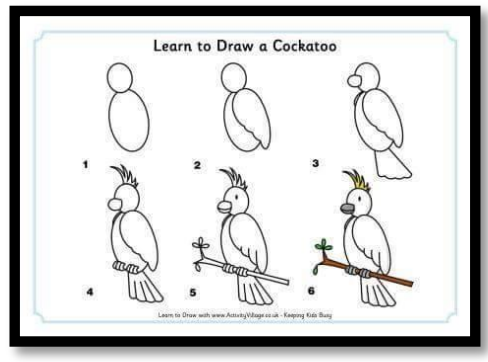

Gambar 1. Pola menggambar burung kakatua (Sumber: https:// cara-menggambar-untuk-anak/)

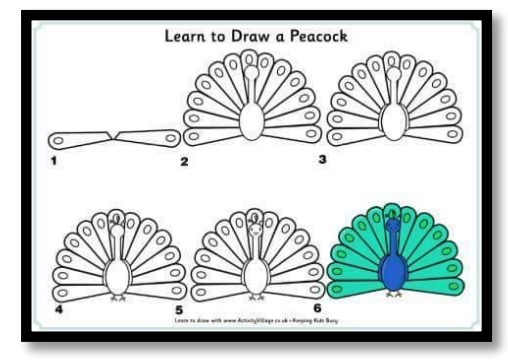

Gambar 2. Pola menggambar burung merak ( Sumber: https:/cara-menggambar-untuk-anak/) 


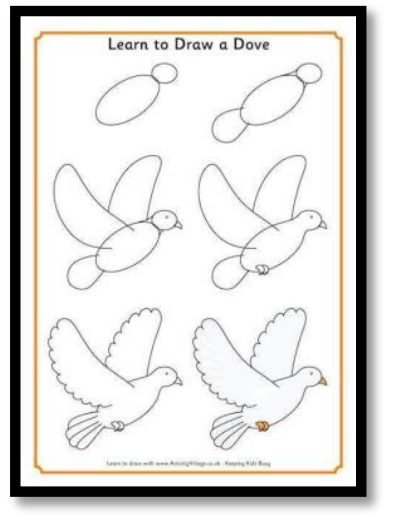

Gambar 3. Pola menggambar burung merpati (Sumber : https://cara-menggambar-untuk-anak/)

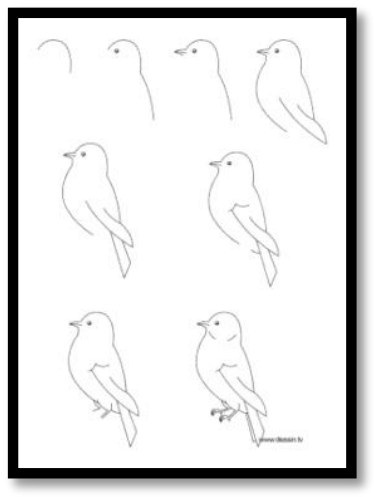

Gambar 4. Pola menggambar burung gereja (Sumber : https://cara-menggambar-hewan/)

\section{METODE PENELITIAN}

Penelitian dilaksankan di SD Swasta Yayasan Pendidikan Wanita Kereta Api Medan "YWKA" yang beralamat J1. Lampu No.2 Pulo Brayan Bengkel Baru, yang memiliki total siswa keseluruhan 253 orang yang terdiri dari kelas I sampai kelas VI. Sebagai objek dalam penelitian ini adalah siswa kelas III yang bejumlah 25 orang. Peneliti memilih sekolah ini sebagai lokasi penelitian dikarenakan pada studi pendahuluan yang peneliti lakukan terlihat masih banyaknya kekurangan dalam pengembangan kreativitas siswa khususnya pada mata pelajaran Seni Rupa dan Keterampilan (SBK) dalam pembelajaran menggambar binatang bertemakan burung dan belum ada penelitan lain yang meneliti tentang variabel yang sama di sekolah ini.

Sesuai rumusan masalah penelitian, penelitian ini dilaksanakan selama dua bulan terhitung dari awal Oktober 2018 sampai dengan akhir Oktober 2018. Sempel pada penelitian ini menggunakan teknik sampling jenuh. Menurut sugiyono (2009:124) Sampling jenuh adalah teknik penentuan sampel bila semua anggota populasi digunakan sebagai sempel . Metode penelitian yang digunakan dalam penelitian ini adalah penelitian melakukan metode penelitian dengan menggunakan pendekatan kualitatif deskriptif. Untuk mengumpulkan data dalam penelitian dilakukan dengan observasi, wawancara, kuesioner (angket), dokumentasi.

\section{HASIL DAN PEMBAHASAN \\ 1.Hasil}

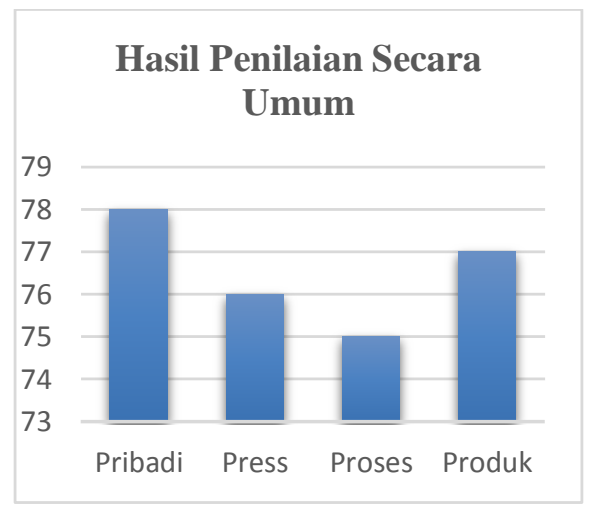

Gambar 5. Hasil Penilaian Secara Umum Sumber : Hasil Penelitian Secara Umum

Berdasarkan data yang telah diambil dati table penilaian, maka semua hasil penelianan dari ketiga ahli secara keseluruhan terdapat hasil karya gambar binatang bertema burung pada siswa kelas III SD Swasta Yayasan Wanita Kereta Api "YWKA" Medan. Bahwa secara umun dikatagorikan cukup baik dengan jumlah rata-rata 77 (cukup baik). Penilaian yang lebih tinggi terdapat pada aspek pribadi kreatif dengan nilai $=78$ (baik), selanjutnya diikuti dengan aspek produk dengan nilai $=77$ (cukup baik), dan selanjutnya diikuti dengan aspek pendorong (press) dengan nilai $=76$ (cukup baik) dan selanjutnya yang paling rendah adalah perinsip proses kreatif dengan nilai $=75$ (cukup baik).

\section{Pembahasan}

Berdasarkan hasil analisis data dalam table penilaian secara umum yang telah diuraikan, maka dapat diketahui nilai secara umum dari penilaian teori tentang $4 \mathrm{p}$ (Pribadi, press, proses, produk ) dari utami munandar pada siswa di kelas III SD Swasta Yayasan Wanita Kereta Api "YWKA" Medan sebagai berikut :

Pribadi memperoleh jumlah nilai $=1952$ dengan ratarata nilai ( $r)=78$ (baik) yang berarti rata-rata karya siswa sudah memenuhi tiga deskriptor dari empat denskriptor yang sudah di tentukan.

Pendorong (press) memperoleh jumlah nilai $=1912$ dengan rata-rata nilai ( $\mathrm{r}$ ) $=76$ (cukup baik) yang 
berarti rata-rata karya siswa sudah memenuhi dua deskriptor dari empat deskriptor yang sudah di tentukan

Proses memperoleh jumlah nilai $=1886$ dengan ratarata nilai ( $r$ ) $=75$ (cukup baik) yang berarti rata-rata karya siswa sudah memenuhi dua deskriptor dari empat deskriptor yang sudah di tentukan

Produk memperoleh jumlah nilai $=1926$ dengan ratarata nilai ( $r$ ) = 77 (cukup baik) yang berarti rata-rata karya siswa sudah memenuhi dua deskriptor dari empat deskriptor yang sudah ditentukan.

\section{KESIMPULAN DAN SARAN}

\section{Kesimpulan}

Berdasarkan hasil penelitian yang dikemukanan maka dapat disimpulkan bahwa kreativitas dan potensi siswa pada kelas III di SD Swasta Yayasan Wanita Kereta Api "YWKA" Medan masih dikatakan cukup baik. Terlihat dari total keseluruhan nilai yang dikumpulkan peneliti dari ke tiga penilai adapun rata-rata nilai adalah 77 dengan katagori cukup baik.

Dari hasil penilaian terlihat bahwa aspek yang paling tinggi nilainya adalah aspek pribadi kreatif dengan nilai rata-rata 78 dengan kategori baik selanjutnya diikuti dengan aspek produk dengan nilai = 77 (cukup baik), dan selanjutnya diikuti dengan aspek pendorong (press) dengan nilai $=76$ (cukup baik) dan selanjutnya yang paling rendah adalah perinsip proses kreatif dengan nilai $=75$ (cukup baik)

Terlihat bahwa kreativitas siswa kelas III SD Swasta Yayasan Wanita Kereta Api "YWKA" cukup baik terlihat dari kemandirian siswa dalam membuat karya, siswa membuat karya tanpa bantuan dari guru maupun teman. Dari hasil karya siswa terlihat juga ketekunan siswa dalam mengerjakan karya tersebut. Kekurangan dalam kreativitas siswa adalah siswa masih kurang memperhatikan sesuatu sehingga siswatidak dapat mengembangkan objek yang ingin digambar karna kurangnya pengalaman siswa dalam mengamati objek -objek yang kan mereka gambar.

Potensi siswa siswa kelas III SD kelas Swasta Yayasan Wanita Kereta Api "YWKA" Medan masih cukup baik namun, potensi mereka masih dapat dikembangkan terlihat dari aspek-aspek yang menonjol dari hasil karya menggambar binatang bertema burung siswa kelas III SD kelas Swasta Yayasan Wanita Kereta Api "YWKA" Medan.

\section{Saran}

Berdasarkan pelaksanaan penelitian yang telah dilakukan peneliti dapat memberikan saran sebagai
Gorga Jurnal Seni Rupa

Volume 08 Nomor 01 Januari-Juni 2019

p-ISSN: 2301-5942 | e-ISSN: 2580-2380

berikut: Kepala sekolah hemdaknya memberi arahan dan memberi motivasi kepada para guru untuk memberikan pembelajaran kreativitas menggambar yang dilakukan anak di sekolah, kepala sekolah mendukung upaya guru menggunakan kegiatan yang tepat untuk mengembangkan kreativitas dan potensi anak, dalam merencanakan kegiatan untuk mengembangkan kreativitas dan potensi menggambar, sebaiknya disusun dengan matang agar pembelajaran dilaksanakan dengan baik, sehingga kreativitas dan potensi siswa berkembang dengan optimal, guru dapat merencanakan lama waktu belajar menggamabar sehingga pembelajaran menyenagkan siswa, orang tua dapat mendukung anak dalam mengembangkan kreativitas dan potensinya dalam menggambar karena motivasi dari orang tua sangat berpengaruh terhadap anak, dan Orang tua sebaikmya memberikan fasilitas yang dibutuhkan oleh anak untuk mengembangkan kreativitas dan potensinya.

\section{DAFTAR RUJUKAN}

Al-Khalili, Aman Abdussalam.

(2005).Mengembangkan Kreativitas Anak.

Jakarta: Pustaka al-Kautsar.

Apriyatno, Very. (2004). Cara Mudah Menggambar

Dengan Pensil. Jakarta: PT Kawan Pustaka.

Mesra. (2013). Gambar bentuk ditinjau dari segi estetika dan kreativitas.Logat:Jurnal Seni Rupa FBS Unimed. 10 (01) 41.

Santrock, Jhon W. (2007). Perkembangan Anak. Jakarta : PT Glora Aksara Pratama.

Sembiring, Dermawan. (2014). Wawasan Seni. Medan: UNIMED PRESS.

Sugiyono. (2010). Metode Penelitian Pendidikan. Bandung: Alfabeta.

Sugito dan Wahyu Tri Atmojo .(2014). Kreativitas dan Tes Wartegg. Jurnal Seni Rupa Universitas Negeri Surbaya, 3 (_) 55.

Susanto, Ahmad. (2013). Teori Belajar \& Pembelajaran di Sekolah Dasar. Jakarta: Prenada Media Group. 